\title{
The Effect of Balance, Arm Muscle Strength, and Creativity towards Discus skills on Faculty of Students of Manado State University Science
}

\author{
Tony Pandaleke ${ }^{1}$, Firmansyah Dlis ${ }^{2}$, Widiastuti ${ }^{2}$ \\ ${ }^{1} \mathrm{Ph} . \mathrm{D}$ Student in Universitas Negeri Jakarta \\ ${ }^{2}$ Lecturer in Universitas Negeri Jakarta \\ Email: tonypandaleke2@gmail.com
}

\begin{abstract}
The aims of the study is to find out The Effect of Balance, Arm Muscle Strength, and Creativity towards Discus skills. This research was carried out on the campus of the Faculty of Sport Science, Manado. State University in Tondano City, Minahasa Regency. This research is a descriptive study. The result of the study is there is a positive direct effect of balance on Discus Throwing Skills at the Faculty of Sport Sciences Mando State University Students. This means that a good balance will result in increased discus throwing skills. There is a positive direct effect of arm muscle strength on discus throwing skills at the students of the Faculty of Sport Science, Mando State University. This means that good arm muscle strength will result in increased discus throwing skills achieved by the student concerned. There is a direct influence on the position of creativity fantasy on discus throwing skills at the Students of the Faculty of Sport Science, Mando State University. This means that good creativity will result in increased disc throwing skills.

Keywords: effect balance; arm muscle strength; discus skills
\end{abstract}

\section{Introduction}

The purpose of national education is so noble, because with the achievement of these goals, all social problems can be overcome including students as the next generation of the nation. Physical education, sports and health is one of the entry points, because it develops; physical fitness, movement skills, critical thinking, social, reasoning, emotional stability, moral actions, aspects of a healthy lifestyle and the introduction of a clean environment through physical activities can be formed by young people who have quality human resources.

Lectures at POR FIK Unima have their own characteristics because the main students will be students to become physical education teachers, whose education uses a lot of physical activities. Students get theoretical and practical lecture material on sports, such as athletics, gymnastics, swimming, volleyball which all must be mastered by students and can even teach it. If students follow practical courses they must have a good physical component as a capital for practical lectures and even lectures carried out in a variety of weather, so perseverance, patience and enthusiasm are needed in order to get good grades in practical subjects.

In this study more directed at the athletics branch more specifically on the number of discus throwing, balance, arm muscle strength, creativity and discus throwing skills. The explanation is as follows: Balance plays an important role in the basic technical movements of the sport. Arm muscle strength is needed by the movement of sports. Students must have creativity in attending lectures to be successful.

Based on the things mentioned above, it will be further investigated about the effect of balance, arm muscle strength and creativity on discus throwing skills at the Faculty of Sport Science, Manado State University. 


\section{Review of Literature}

\subsection{Definition of Athletics}

Athletics is a physical activity that consists of basic movements that are dynamic and harmonious, namely walking, running, jumping, and throwing. When viewed from the meaning or the term "athletics" comes from the Greek Athlon or Athlum which means "race or race / competition". America and parts of Europe and Asia often use the term / word athletic with Track and Field and Germany uses the word Leicht Athletic and the Dutch state uses the term / word Athletiek.

Athletics is also a means for physical education in an effort to improve biomotor abilities, for example strength, endurance, speed, flexibility, coordination, and so on. It also serves as a means for research for scientists.

Athletics is an ancient sport because it has been contested since the first Olympics. According to Happy Yoyo, Ucup Yusup, and Adang Suherman the term athletics comes from the Greek word "athlon" which means to compete or compete. While the definition of athletics according to Rud Midgley, C.S. as follows: "Athletics is a type of sport that includes a variety of competitions with different skills. But the main thing is there are 2 types, namely track (track) and field (field). "Track" consists of running short, medium, obstacle, and long distance. While the "field" includes throwing and jumping.

\subsection{Definition of Throwing Discs}

To understand the meaning of discus throwing, we first understand the meaning of discus throwing. According to W. J. S. Poerwadarminta in Indonesian public dictionary throwing is a sport by throwing (javelin, bullets, hammerheads, discs). While the understanding of discs according to Didi Sugandi is a wooden object in the form of a plate rimmed with an iron belt. So discus throwing is one of the numbers in athletics that uses a wooden object in the form of an iron belt, or other flat rounded material that is thrown.

According to Eddy Purnomo the characteristics of a good discus thrower are that he has a tall, strong body and has speed of movement, good coordination power and special mobility. A discus thrower must also have a maximum level of strength and the strength of the acceleration of the muscles at the time of movement, the strength of the recative throw for the final acceleration motion of the disc. According to Rud Midgley, C.S discs are made of metal / slippery, have a strong adhesion to the body of the disc or other suitable material. It weighs centered, at least $2 \mathrm{~kg}$ for men, and $1 \mathrm{~kg}$ for women. Discus throw is one of the branches of athletic sports. Throwed discs measuring $220 \mathrm{~mm}$ in diameter and weighing $2 \mathrm{~kg}$ for men, $1 \mathrm{~kg}$ for women. Discus throw has been contested since the Olympic Games of 1896 in Athens, Greece.

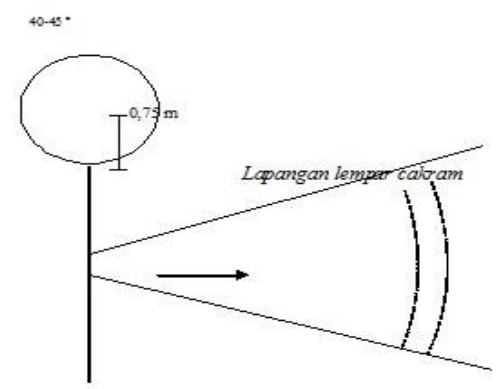

Figure 1. Disc throwing field

Source: http://aadesanjaya.blogspot.com 


\subsection{Balance}

Balance is one of the physical conditions that cannot be released in any sport including discus throwing, balance discs are very necessary when going to make a movement in throwing discs such as going to swing, rotate, move the feet, and release the discs. while M Sajoto said that balance is the ability to control the nerve organs of the muscles. Therefore a person when going to make a balance motion is not directly related directly to other limbs.

Balance is one of the physical conditions that cannot be released in any sport including discus throwing, balance discs are very necessary when going to make a movement in throwing discs such as going to swing, rotate, move the feet, and release the discs. While M Sajoto said that the balance is the ability to control the nerve organs of the muscles. Therefore a person when going to make a balance of motion is not directly related directly to other limbs.

\section{Research Method}

This research was carried out on the campus of the Faculty of Sport Science, Manado. State University in Tondano City, Minahasa Regency. The research took place from August to September 2013, starting from the sample survey, the selection and preparation of data collection instruments, to the implementation of data collection in this case testing and measurement.

This research is a descriptive study that aims to make a systematic description of the relationship between the factors being investigated and that is why this study uses a survey method with Path Analysis.

\section{Discussion}

In this section presents the results of research that will be presented in sequence regarding: description of research data, testing of analysis requirements, testing hypotheses, discussion and limitations of research.

\subsection{Description of Research Result Data}

Description of the data from the results of the study aims to provide a general description of the distribution of data distribution, both in the form of a size distribution of the frequency distribution. Prices are presented after being processed from raw data using descriptive statistical methods, namely the maximum value, minimum value, range, average, standard deviation and variance. Summary of statistical calculation results as follows:

Table 1. Summary of Research Results

\begin{tabular}{|l|c|c|c|c|}
\hline \multirow{2}{*}{\multicolumn{1}{c|}{ Statistics }} & \multicolumn{4}{c|}{ Variables } \\
\cline { 2 - 5 } & $\mathrm{X}_{1}$ & $\mathrm{X}_{2}$ & $\mathrm{X}_{3}$ & $\mathrm{Y}$ \\
\hline Number of Samples (n) & 70 & 70 & 70 & 70 \\
\hline Maximum Score & 50 & 70 & 209 & 48 \\
\hline Minimum Score & 15 & 35 & 168 & 28 \\
\hline Range & 35 & 35 & 41 & 20 \\
\hline Average $(\dot{\mathrm{X}})$ & 35,43 & 52,59 & 188,66 & 38,40 \\
\hline Standard Deviation $(\mathrm{s})$ & 8,79 & 8,72 & 9,95 & 5,23 \\
\hline Varians $\left(\mathrm{s}^{2}\right)$ & 77,35 & 76,01 & 99,04 & 27,37 \\
\hline
\end{tabular}

Information:

$\mathrm{X} 1$ : Balance

X2: Arm Muscle Strength 
X3: Creativity

Y: Disc throwing skills

The description of the data presented is a description of the research variables studied consisting of three variables consisting of two exogenous variables (independent) and one endogenous variable (bound). Exogenous variables consist of balance, arm muscle strength, and creativity. Endogenous variables consist of discus throwing skills. Presentation of data descriptions are presented for each variable in a row starting from the dependent variable as follows:

\section{a. Discus Throwing Skills}

Based on research data for discus throwing skills obtained the lowest score of 28 , and the highest score of 48 , with a range of scores of 20 , from the results of data analysis obtained an average of 38.40; standard deviation 5.23; and variance 27.37. With lots of class 7 and class 3 length, frequency distribution of variable data on the discus throwing skill as Table 2 . To further clarify the presentation, the discus throwing skill data is also presented in the form of a histogram like Figure 2.

Table 2. List of Frequency of iscus throwing skills in the students of the Faculty of Sport Sciences Manado State University

\begin{tabular}{|c|c|c|c|c|}
\hline \multirow{2}{*}{ No } & \multirow{2}{*}{ Interval Class } & \multicolumn{3}{|c|}{ Frequency } \\
\cline { 3 - 5 } & & Absolute & Relatively (\%) & Cumulative (\%) \\
\hline 1 & $28-30$ & 6 & 8,57 & 8,57 \\
\hline 2 & $31-33$ & 9 & 12,86 & 21,43 \\
\hline 3 & $34-36$ & 12 & 17,14 & 38,57 \\
\hline 4 & $37-39$ & 15 & 21,43 & 60 \\
\hline 5 & $40-42$ & 12 & 17,14 & 77,14 \\
\hline 6 & $43-45$ & 10 & 14,29 & 91,43 \\
\hline 7 & $46-48$ & 6 & 8,57 & 100 \\
\hline \multicolumn{7}{r}{} & Total & 70 & 100 & \\
\hline
\end{tabular}

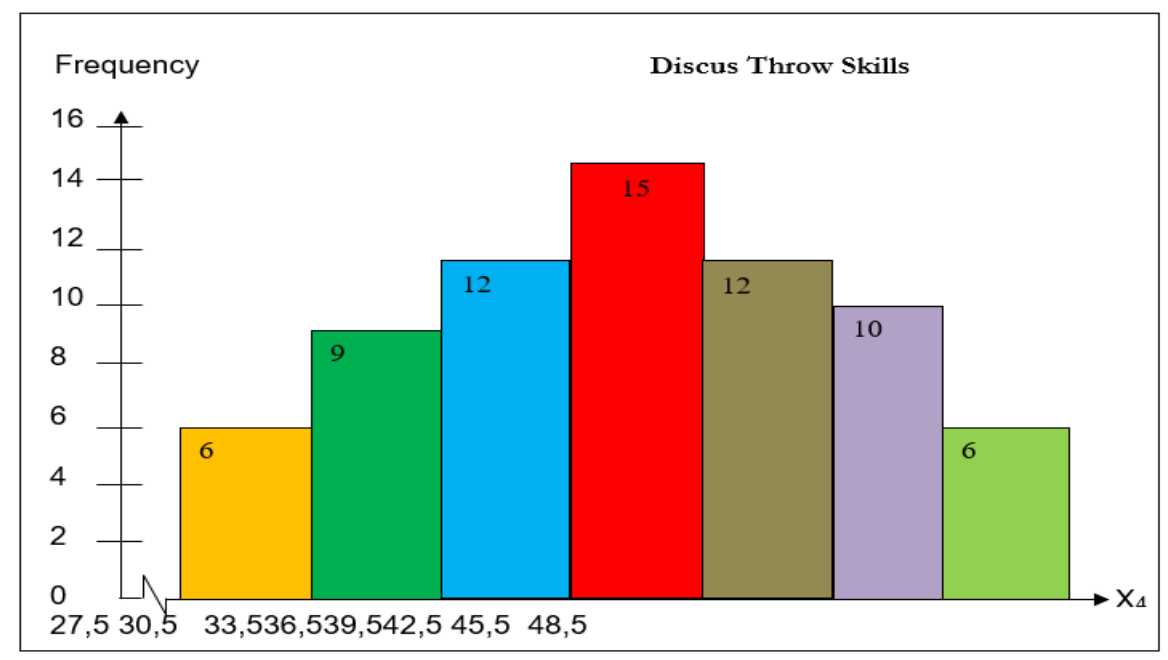

Figure 2. Histogram Data Variable Discus Throwing Skills 
Data regarding the balance obtained through the test shows the range of empirical scores between 15 and 50, with a theoretical range of scores of 50-50. The calculation results show an average price of 35.43; standard deviation 8.79; and Variance 77,35. With the number of class intervals 7 and length of class 5 the frequency distribution can be seen in Table 3 and the histogram as Figure 3.

Table 3. List of Frequency Balance Scores

\begin{tabular}{|c|c|c|c|c|}
\hline \multirow{2}{*}{ No } & \multirow{2}{*}{ Class Interval } & \multicolumn{3}{|c|}{ Frequency } \\
\cline { 3 - 5 } & & Absolute & Relative $(\%)$ & Cumulative (\%) \\
\hline 1 & $15-20$ & 5 & 7,14 & 7,14 \\
\hline 2 & $21-25$ & 8 & 11,43 & 18,57 \\
\hline 3 & $26-30$ & 12 & 17,14 & 35,71 \\
\hline 4 & $31-35$ & 17 & 24,29 & 60 \\
\hline 5 & $36-40$ & 12 & 17,14 & 77,14 \\
\hline 6 & $41-45$ & 9 & 12,86 & 90 \\
\hline 7 & $46-50$ & 7 & 10 & 100 \\
\hline \multicolumn{2}{|c|}{ Total } & 70 & 100 & \\
\hline
\end{tabular}

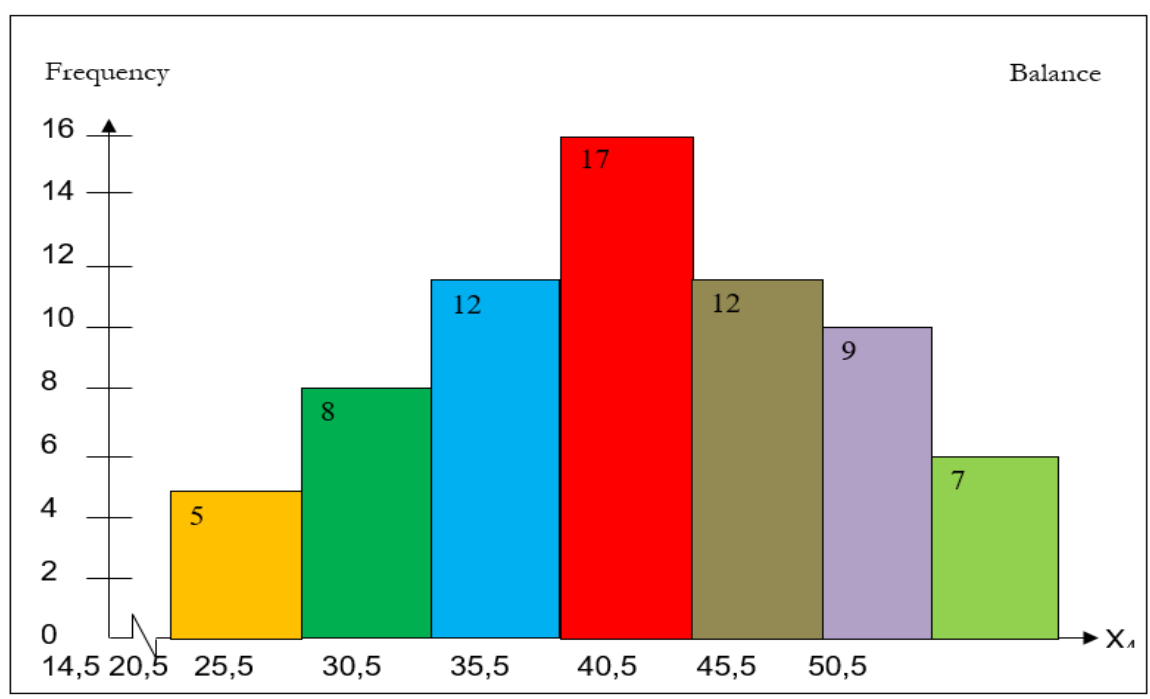

\section{b. Arm Muscle Strength}

Figure 3. Balance Variable Data Histogram

Data on arm muscle strength from the results of the study showed the range of empirical scores between 35 and 70 . The average price calculation results were 52.59; standard deviation 8.72; and variance 76.01. With the number of interval classes 7 and the length of the interval class 5 the frequency distribution can be seen in Table 6 and the histogram in Figure 4 .

Table 4. List of Frequencies for Arm Muscle Strength Scores

\begin{tabular}{|c|c|c|c|c|}
\hline \multirow{2}{*}{ No } & \multirow{2}{*}{ Class Interval } & \multicolumn{3}{|c|}{ Frequency } \\
\cline { 3 - 5 } & & Absolute & Relatively (\%) & Cumulative (\%) \\
\hline 1 & $35-40$ & 5 & 7,14 & 7,14 \\
\hline 2 & $41-45$ & 9 & 12,86 & 20 \\
\hline 3 & $46-50$ & 12 & 17,14 & 37,14 \\
\hline 4 & $51-55$ & 16 & 22,86 & 60 \\
\hline 5 & $56-60$ & 12 & 17,14 & 77,14 \\
\hline 6 & $61-65$ & 10 & 14,29 & 91,34 \\
\hline 7 & $66-70$ & 6 & 8,57 & 100 \\
\hline \multicolumn{2}{|c|}{ Total } & 70 & 100 & \\
\hline
\end{tabular}




\section{c. Creativity}

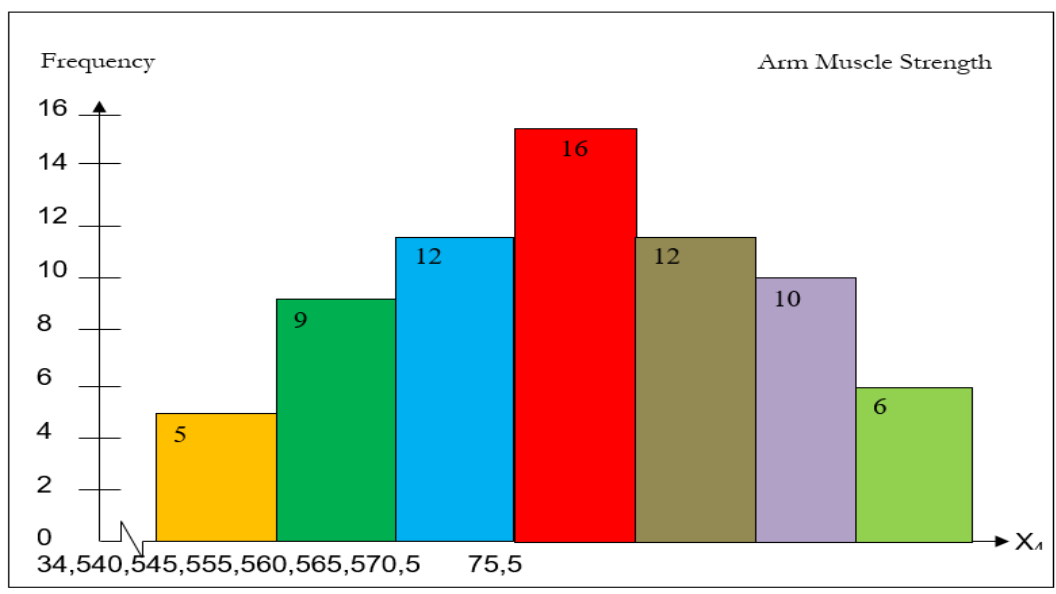

Figure 4. Variable Data Histograms of Arm Muscle Strength

Based on research data for creativity scores, which have a range of theoretical scores of 20 , obtained the lowest score of 168 , the highest score of 209 , with a range of scores of 41 , from the results of data analysis obtained an average of 188.66; 9.95 standard deviation. With many classes 7 and class 6 lengths, the frequency distribution of creativity variable data is made as in Table 5. To further clarify the presentation, the creativity data is also presented in the form of a histogram like Figure 5.

Table 5. List of Frequencies of Creativity Scores

\begin{tabular}{|c|c|c|c|c|}
\hline \multirow{2}{*}{ No } & \multirow{2}{*}{ Class Interval } & \multicolumn{3}{|c|}{ Frequency } \\
\cline { 3 - 5 } & & Absolute & Relatively (\%) & Cumulative (\%) \\
\hline 1 & $168-173$ & 5 & 7,14 & 7,14 \\
\hline 2 & $174-179$ & 8 & 11,43 & 18,57 \\
\hline 3 & $180-185$ & 14 & 20 & 38,57 \\
\hline 4 & $186-191$ & 16 & 22,86 & 61,43 \\
\hline 5 & $192-197$ & 14 & 20 & 81,43 \\
\hline 6 & $198-203$ & 8 & 11,43 & 92,86 \\
\hline 7 & $204-209$ & 5 & 7,14 & 100 \\
\hline \multicolumn{7}{r}{ Total } & 70 & 100 & \\
\hline
\end{tabular}

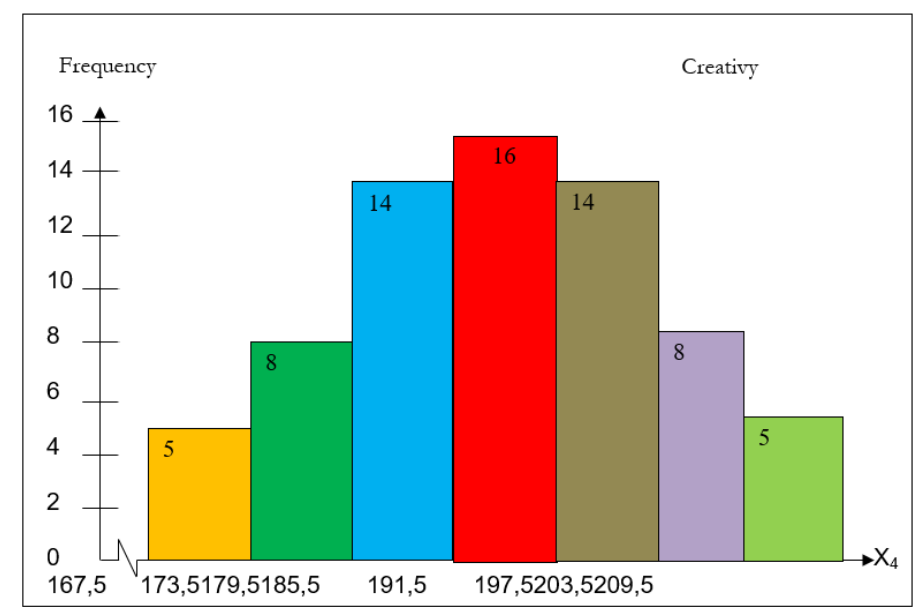

Figure 5. Creativity Variable Data Histogram 


\subsection{Testing Requirements Analysis}

Since data processing in this study uses statistical tests with path analysis techniques, it is necessary to test the analysis requirements, so the results can be used to draw conclusions. Requirements for path analysis are the distribution of normally distributed data, the variance of the data is homogeneous and the causal relationship between variables is linear. Based on these requirements, the following tests are carried out:

- Test the estimated normality of error data using the Liliefors test.

- Test the variance homogeneity with the Barlett test.

- Test the significance and linearity of the data with a regression test.

\section{a. Test the Normality of Estimated Error Data}

To see whether the data obtained from each of the research variables is normal or not, a normality test is done using the Liliefors test. If the result of the highest $\mathrm{L}_{\text {count }}\left(\mathrm{L}_{0}\right)$ price of the examined variable group is smaller than the $\mathrm{L}_{\text {table }}(\mathrm{Lt})$ in the list, then the data is said to be normally distributed.

While what is meant by $\mathrm{L}_{\text {count }}\left(\mathrm{L}_{0}\right)$ is the difference between the largest absolute price between the standard score opportunity and the standard score proportion (| F (zi) -S (zi) |). For more details, the normality calculation results of the variables examined will be presented using the liliefors test at the significance level $\alpha=0.05$.

- The normality error test of the estimation equation $\mathrm{X}_{4}$ over $\mathrm{X}_{1}$. The equilibrium regression equation for discus throwing skills, is $\mathrm{X}_{4}=-0.17 .74+0.58 \mathrm{X} 1$, based on the calculation results of the normality test for liliefors, the $\mathrm{L}_{0}$ value is 0.0551 . Where the critical value of $\mathrm{L}_{0}$ in the Liliefors table for sample size $(\mathrm{n})=70$ with $\alpha=0.05$ obtained a value of 0.125 . When compared to the calculated $\mathrm{L}_{0}$ value it turns out to be smaller than the L0 table, so it can be concluded that the estimated error of the regression equation $\mathrm{X}$ $=17.74+0.58 \mathrm{X}_{1}$, has a normal distribution.

- The normality error test for estimating the regression equation $\mathrm{X}_{4}$ over $\mathrm{X}_{2}$. Structural equation of arm muscle strength for discus throwing skills, is $\mathrm{X}_{2}=61,267+0.395 \mathrm{X} 2$, based on the calculation results of the normality of liliefors test, the $\mathrm{L}_{0}$ value is 0.1075 . Where the critical value of $L_{0}$ in the Liliefors table for sample size (n) $=70$ with $\alpha=0.05$ obtained a value of 0.125 . When compared to the calculated $\mathrm{L}_{0}$ value it turns out to be smaller than the $\mathrm{L}_{0}$ table, so it can be concluded that the estimated error of the regression equation $\mathrm{Y}=61.267+0.395 \mathrm{X} 2$, has a normal distribution.

- Test normality error estimated regression equation $\mathrm{X}_{4}$ over $\mathrm{X}_{3}$. Structural equations of discus throwing skills on creativity, are $\mathrm{X}_{4}=-0.332+0.03 \mathrm{X} 3$, based on the calculation results of the liliefors normality test obtained a $\mathrm{L}_{0}$ value of 0.0557 . Where the critical value of $\mathrm{L}_{0}$ in the Liliefors table for sample size $(\mathrm{n})=70$ with $\alpha=0.05$ obtained a value of 0.125 . When compared to the calculated $\mathrm{L}_{0}$ value it turns out to be smaller than the $\mathrm{L}_{0}$ table, so it can be concluded that the estimated error of the regression equation $\mathrm{X}_{4}=-$ $0.332+0.03 \mathrm{X}_{3}$, has a normal distribution.

- The normality error test for estimation of the regression equation $\mathrm{X}_{3}$ over $\mathrm{X}_{1}$. The equation of the regression of creativity to equilibrium, is $\mathrm{X}_{3}=-0.792+0.30 \mathrm{X}_{1}$, based on the calculation results of the liliefors normality test, the $\mathrm{L}_{0}$ value is 0.0552 . Where the critical value of $\mathrm{L}_{0}$ in the Liliefors table for sample size $(\mathrm{n})=70$ with $\alpha=0.05$ obtained a value of 0.125 . When compared to the calculated $\mathrm{L} 0$ value it turns out to be smaller than the $\mathrm{L}_{0}$ table, so it can be concluded that the estimated error of the regression equation $\mathrm{X}_{3}$ $=-0.792+0.30 \mathrm{X}_{1}$, has a normal distribution. 
- The normality error test for estimating the regression equation $\mathrm{X}_{3}$ over $\mathrm{X}_{2}$. The structural equation for creativity on arm muscle strength, is $\mathrm{X} 3=21.34+0.95 \mathrm{X} 2$, based on the calculation results of the liliefors normality test, the $\mathrm{L}_{0}$ value is 0.1072 . Where the critical value of $\mathrm{L} 0$ in the Liliefors table for sample size $(\mathrm{n})=70$ with $\alpha=0.05$ obtained a value of 0.125 . When compared to the calculated $\mathrm{L}_{0}$ value it turns out to be smaller than the $\mathrm{L}_{0}$ table, so it can be concluded that the estimated error of the regression equation $\mathrm{X}_{3}=$ $21.34+0.95 \mathrm{X}_{2}$, has a normal distribution.

Table 6. Summary of normality test results

\begin{tabular}{|l|l|l|l|}
\hline \multicolumn{1}{|c|}{ Estimated Error } & \multicolumn{1}{|c|}{$\mathrm{L}_{0}$ count } & $\mathrm{L}_{0}$ table & Conclusion \\
\hline $\mathrm{Y}$ up $\mathrm{X}_{1}$ & 0,0551 & 0,125 & Normal \\
\hline $\mathrm{Y}$ up $\mathrm{X}_{2}$ & 0,1075 & 0,125 & Normal \\
\hline $\mathrm{Y}$ up $\mathrm{X}_{3}$ & 0,0557 & 0,125 & Normal \\
\hline $\mathrm{X}_{3}$ up $\mathrm{X}_{1}$ & 0,0552 & 0,125 & Normal \\
\hline $\mathrm{X}_{3}$ up $\mathrm{X}_{2}$ & 0,1072 & 0,125 & Normal \\
\hline
\end{tabular}

\subsection{Variance Homogeneity Test}

To test the homogeneity of variance in this study the Bartlett test was used. If the result of the calculated $\alpha 2$ value of the group of variables studied is smaller than the $\alpha 2$ table at $\alpha=0.05$, then the data is said to be homogeneous variance.

\section{a. Homogeneity Test of Variance $\mathbf{X}_{4}$ over $\mathbf{X}_{1}$}

The homogeneity variance test calculation results on the discus throwing skills obtained $\alpha 2$ count value of 1.56 . Where the critical value $\alpha 2$ table for degrees of freedom $(\mathrm{dk})=18$ with $\alpha$ $=0.05$ obtained a value of 28.87 . When compared to the calculated $\alpha 2$ value it turns out to be smaller than $\alpha 2$ table, so it can be concluded that the variance of $\mathrm{X} 4$ and $\mathrm{X} 1$ groups is homogeneous.

\section{b. Homogeneity Test of Variance $\mathbf{X}_{4}$ over $\mathbf{X}_{2}$}

The results of the homogeneity test variance in arm muscle strength over discus throwing skills were obtained $\alpha 2$ count value of 0.00 . Where the critical value $\alpha 2$ table for degrees of freedom $(\mathrm{dk})=26$ with $\alpha=0.05$ obtained a value of 38.89. When compared to the calculated $\alpha 2$ value it turns out to be smaller than $\alpha 2$ table, so it can be concluded that the variance of group $\mathrm{X}_{4}$ over $\mathrm{X}_{2}$ is homogeneous.

\section{c. Homogeneity Test of Variance $\mathrm{X}_{3}$ over $\mathrm{X}_{1}$}

The results of the homogeneity test of the variance of the equilibrium to the strength of the arm muscle obtained a calculated $\alpha 2$ value of 10.51 . Where the critical value $\alpha 2$ table for degrees of freedom $(\mathrm{dk})=23$ with $\alpha=0.05$ obtained a value of 35.17 . When compared to the calculated $\alpha 2$ value it turns out to be smaller than $\alpha 2$ table, so it can be concluded that the variance of group $\mathrm{X}_{3}$ over $\mathrm{X}_{1}$ is homogeneous.

\section{d. Homogeneity Test of Variance $\mathbf{X}_{3}$ over $\mathbf{X}_{2}$}

The results of the homogeneity test for the variance of the balance to the strength of the arm muscle obtained a calculated $\alpha 2$ value of 10.51 . Where the critical value $\alpha 2$ table for degrees of freedom $(\mathrm{dk})=23$ with $\alpha=0.05$ obtained a value of 35.17 . When compared to the calculated $\alpha 2$ value it turns out to be smaller than $\alpha 2$ table, so it can be concluded that the variance of group $\mathrm{X}_{3}$ over $\mathrm{X}_{2}$ is homogeneous. 


\section{e. Homogeneity Test of Variance $\mathbf{X}_{4}$ over $\mathbf{X}_{3}$}

The results of the homogeneity test variance of discus throwing skills on creativity obtained $\alpha 2$ count value of 10.51 . Where the critical value $\alpha 2$ table for degrees of freedom $(\mathrm{dk})=$ 23 with $\alpha=0.05$ obtained a value of 35.17 . When compared to the calculated $\alpha 2$ value it turns out to be smaller than $\alpha 2$ table, so it can be concluded that the variance of group $\mathrm{X}_{3}$ over $\mathrm{X}_{2}$ is homogeneous.

\subsection{Model Testing}

Before calculations are performed to test the causality model, which uses the path analysis model, then as previously explained the research data has been tested and fulfills all the necessary requirements.

One very important requirement that must be met is the existence of a significant correlation between related variables and related to each other. However, the effect that has been proven through the magnitude of the correlation coefficient does not infer a causal occurrence between one of these variables.

After the data obtained from the field is processed and has passed various test requirements analysis, the next step in testing the causality model is to do a path analysis.

Based on the causal model formed theoretically a path analyst diagram will be obtained and coefficient values calculated for each path.

Table 7. Correlation Coefficient Matrix and Path between Variable Paths

\begin{tabular}{|l|c|c|c|c|c|}
\hline & $\begin{array}{c}\mathrm{R} \\
\text { (koef korelasi) }\end{array}$ & $\begin{array}{c}\mathrm{P} \\
\text { (koef jalur) }\end{array}$ & $\mathrm{T}_{\text {count }}$ & $\begin{array}{c}\mathrm{t}_{\text {table }} \\
(0,05)\end{array}$ & Information \\
\hline $\mathrm{X}_{1} \rightarrow \mathrm{X}_{4}$ & 0.980 & 0.961 & 41,104 & 0.015 & Significant pathway \\
\hline $\mathrm{X}_{2} \rightarrow \mathrm{X}_{4}$ & 0,997 & 0.994 & 103,746 & 0.001 & Significant pathway \\
\hline $\mathrm{X}_{3} \rightarrow \mathrm{X}_{4}$ & 0.994 & 0.987 & 72,338 & 0.001 & Significant pathway \\
\hline $\mathrm{X}_{1} \rightarrow \mathrm{X}_{3}$ & 0,983 & 0,966 & 43,861 & 0.001 & Significant pathway \\
\hline $\mathrm{X}_{2} \rightarrow \mathrm{X}_{3}$ & 0,997 & 0,995 & 113,107 & 0.001 & Significant pathway \\
\hline
\end{tabular}

\subsection{Hypothesis Testing}

After analyzing the structural model, the results obtained are used to test the proposed hypothesis and measure the amount of direct influence between variables. The conclusion of the proposed hypothesis will be drawn through the path coefficient and significance test for each path examined.

\section{a. Positive Direct Effect of Balance on Discus Throwing Skills.}

This hypothesis can be formulated statistically as follows:

$\mathrm{H} 0: \beta 41 \leq 0$

$\mathrm{H} 1: \beta 41>0$ 
The results of the calculation of the path coefficient and $t$ arithmetic, to test the above hypothesis are presented in the following table:

Table 8. Hypothesis Testing of Balance towards Discus Throwing Skills.

\begin{tabular}{|c|c|c|c|c|}
\hline \multirow{2}{*}{$\begin{array}{c}\text { Number of } \\
\text { observations }(\mathrm{n})\end{array}$} & \multirow{2}{*}{ Path coefficient $(\varrho 41)$} & \multirow{2}{*}{$\mathrm{T}_{\text {count }}$} & \multicolumn{2}{|c|}{$\mathrm{t}_{\text {table }}$} \\
\cline { 4 - 5 } & & $41,104^{*}$ & $\alpha=0,05$ & $\alpha=0,01$ \\
\hline 70 & 0.961 & 4,994 & 2,648 \\
\hline
\end{tabular}

Information:

$*=$ The path coefficient is very significant, $\mathrm{t}_{\text {count }}(41.104)>\mathrm{t}_{\text {table }}$ at $\alpha=0.01 ; \mathrm{dk}(70)=(2,648$

The calculation results as seen in the table above show that the path coefficient of Balance to Discus Throwing Skills $(\varrho 41)=0.098$ with $t_{\text {count }}=41.104$. Because $t_{\text {count }}=41.104$ and $\mathrm{t}_{\text {table }}=2.648$ at $\alpha=0.01$, then $\mathrm{t}_{\text {count }}>\mathrm{t}_{\text {table }}, 41.104>2.648$, then $\mathrm{H}_{0}$ is rejected which means there is a positive direct effect of Balance on Discus Throwing Skills.

\section{b. Positive Direct Effect of Balance on Creativity.}

This hypothesis can be formulated statistically as follows:

$\mathrm{H} 0: \beta 31 \leq 0$

$\mathrm{H} 1: \beta 31>0$

The results of the calculation of the path coefficient and $t_{\text {count, }}$ to test the above hypothesis are presented in the following table:

Table 9. Testing the Hypothesis of Balance towards Creativity

\begin{tabular}{|c|c|c|c|c|}
\hline $\begin{array}{c}\text { Number of } \\
\text { observations }(\mathrm{n})\end{array}$ & Path coefficient $(\varrho 31)$ & $\mathrm{T}_{\text {count }}$ & \multicolumn{2}{|c|}{$\mathrm{t}_{\text {table }}$} \\
\cline { 4 - 5 } & & & $\alpha=0,05$ & $\alpha=0,01$ \\
\hline 70 & 0,966 & $43,861^{*}$ & 1,994 & 2,648 \\
\hline
\end{tabular}

Information:

$*=$ The path coefficient is very significant, $\mathrm{t}_{\text {count }}(43,861)>\mathrm{t}_{\text {table }}$ at $\alpha=0.01 ; \mathrm{dk}(70)=(2,648)$

The calculation results as seen in the table above shows that the path coefficient of Balance to Creativity ( $\varrho 31)=0.966$ with $\mathrm{t}_{\text {count }}=43.861$. Because $\mathrm{t}_{\text {count }}=43.861$ and ttable $=2.648$ at $\alpha=0.01$, then $t_{\text {count }}>t_{\text {table }}, 43.861>2.648$, then $H_{0}$ is rejected, which means there is a positive direct effect of Balance on Creativity.

\section{c. Positive Direct Effect of Arm Muscle Strength on Disc Throwing Skills.}

This hypothesis can be formulated statistically as follows:

H0: $\beta 42 \leq 0$

H1: $\beta 42>0$

The results of the calculation of the path coefficient and tcount, to test the above hypothesis are presented in the following table:

Table 10. Hypothesis Testing of Arm Muscle Strength towards Discus Throwing Skills

\begin{tabular}{|c|c|c|c|c|}
\hline \multirow{2}{*}{$\begin{array}{c}\text { Number of } \\
\text { observations }(\mathrm{n})\end{array}$} & \multirow{2}{*}{ Path coefficient $(\varrho 42)$} & \multirow{2}{*}{$\mathrm{T}_{\text {count }}$} & \multicolumn{2}{|c|}{$\mathrm{t}_{\text {table }}$} \\
\cline { 4 - 5 } & & & $\alpha=0,05$ & $\alpha=0,01$ \\
\hline 70 & 0,994 & $103,746^{*}$ & 1,994 & 2,648 \\
\hline
\end{tabular}

Information:

$*=$ Path coefficient is very significant, $\mathrm{t}_{\text {count }}(103,746)>$ table on $\alpha=0.01 ; \mathrm{dk}(70)=(2,648)$

The calculation results as seen in the table above show that the path coefficient of the Arm Muscle Strength against the Discus Throwing Skill $(\varrho 42)=0.994$ with $t=103.746$. Because $\mathrm{t}_{\text {count }}=103.746$ and $\mathrm{t}_{\text {table }}=2.648$ at $\alpha=0.01$, then $\mathrm{t}_{\text {count }}>\mathrm{t}_{\text {table, }}, 103.746>2.648$, then $\mathrm{H}_{0}$ is rejected, 
which means there is a positive direct effect of Arm Muscular Strength on Discus Throwing Skills.

\section{d. Positive Direct Effect of Arm Muscle Strength on Creativity.}

This hypothesis can be formulated statistically as follows:

$\mathrm{H} 0: \beta 32 \leq 0$

$\mathrm{H} 1: \beta 32>0$

The results of the calculation of the path coefficient and $t_{\text {count, }}$ to test the above hypothesis are presented in the following table:

Table 11. Hypothesis Testing of Arm Muscle Strength against Creativity

\begin{tabular}{|c|c|c|c|c|}
\hline \multirow{2}{*}{$\begin{array}{c}\text { Number of } \\
\text { observations }(\mathrm{n})\end{array}$} & \multirow{2}{*}{ Path coefficient $(\varrho 32)$} & \multirow{2}{*}{$\mathrm{T}_{\text {count }}$} & \multicolumn{2}{|c|}{$\mathrm{t}_{\text {table }}$} \\
\cline { 4 - 5 } & & $113,107^{*}$ & $\alpha=0,05$ & $\alpha=0,01$ \\
\hline 70 & 0,995 & 1,994 & 2,048 \\
\hline
\end{tabular}

Information:

$*=$ The path coefficient is very significant, $\mathrm{t}_{\text {count }}(113,107)>\mathrm{t}_{\text {table }}$ at $\alpha=0.01 ; \mathrm{dk}(70)=(2,648)$

The calculation results as seen in the table above shows that the path coefficient of the Arm Muscle Strength to Creativity ( $\varrho 32)=0.995$ with $t_{\text {count }}=113.107$. Because $t_{\text {count }}=113.107$ and $t_{\text {table }}=2.648$ at $\alpha=0.01$, then $t_{\text {count }}>t_{\text {table }}, 113.107>2.648$, then $H_{0}$ is rejected which means there is a positive direct effect of Arm Muscular Strength on Creativity.

\section{e. Positive Direct Effect of Creativity on Discus Throwing Skills}

This hypothesis can be formulated statistically as follows:

H0: $\beta 43 \leq 0$

H1: $\beta 43>0$

The results of the calculation of the path coefficient and tcount, to test the above hypothesis are presented in the following table:

Table 12. Creativity Hypothesis Testing of Discus Throwing Skills

\begin{tabular}{|c|c|c|c|c|}
\hline \multirow{2}{*}{$\begin{array}{c}\text { Number of } \\
\text { observations }(\mathrm{n})\end{array}$} & \multirow{2}{*}{ Path coefficient $(\varrho 43)$} & \multirow{2}{*}{$\mathrm{T}_{\text {count }}$} & \multicolumn{2}{|c|}{$\mathrm{t}_{\text {table }}$} \\
\cline { 4 - 5 } & & & $\alpha=0,05$ & $\alpha=0,01$ \\
\hline 70 & 0,987 & $72,338^{*}$ & 1,994 & 2,648 \\
\hline
\end{tabular}

Information:

$*=$ The path coefficient is very significant, $\mathrm{t}_{\text {count }}(72,338)>\mathrm{t}_{\text {table }}$ at $\alpha=0.01 ; \mathrm{dk}(70)=(2,648)$

The calculation results as seen in the table above show that the coefficient of the Creativity path to the Discus Throwing Skill $(\varrho 43)=0.987$ with $t=72.333$. Because $t_{\text {count }}=$ 72.333 and $t_{\text {table }}=2.648$ at $\alpha=0.01$, then $t_{\text {count }}>t_{\text {table, }}, 72.333>2.648$, then $H_{0}$ is rejected which means there is a positive direct effect of Creativity on Discus Throwing Skills. The path coefficient of each variable can be described as follows:

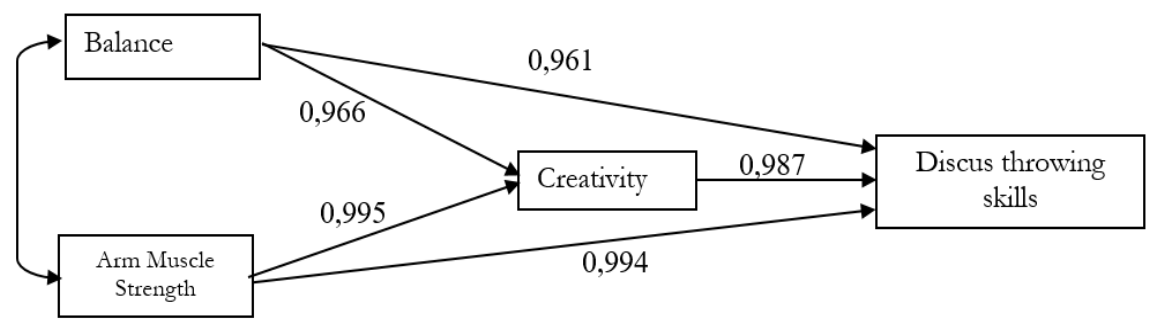

Figure 6. Path diagram for Path coefficient 
Based on the calculation results of each exogenous variable to the endogenous variable, two sub-structural equation models are obtained:

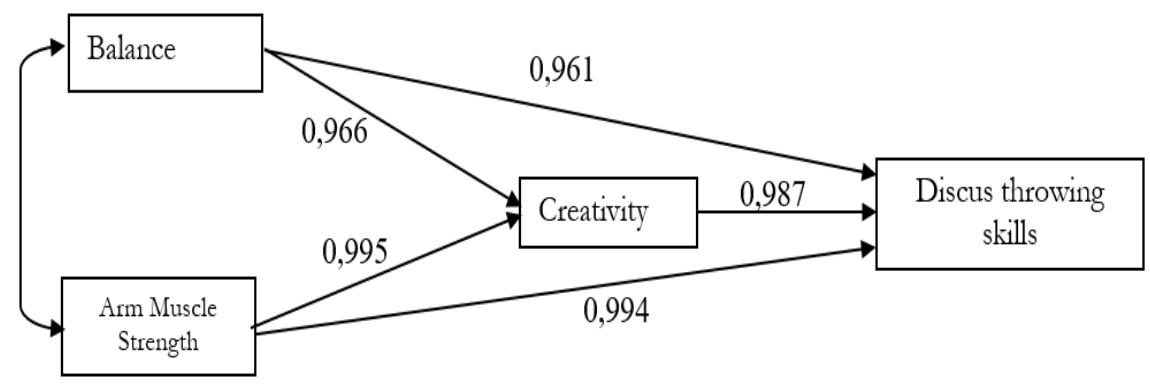

Figure 7. Substructural model of the influence of Arm Muscle Balance and Strength on Creativity

The mathematical equation from figure 15 . Above is $\mathrm{X} 3=0.966 \mathrm{X} 1+0.995 \mathrm{X} 2+0.005$. Based on the sub-structural equation model 1 above, it can be explained that creativity as an endogenous variable is directly affected by the Balance and Arm Muscle Strength as an exogenous variable and other factors. The magnitude of the contribution of Balance and Arm Muscle Strength simultaneously affecting Creativity is $1-0.995=0.005$.

This figure shows the positive direct effect of Arm Muscle Balance and Strength on Creativity by 0.995 , while the remaining 0.005 is influenced by other factors. In other words, the variability of creativity that can be explained by using the Balance and Arm Muscle Strength variable is 0.995 , while the effect of 0.005 is caused by other variables outside the model.

In sub-structure 2 shows the combined and partial effect between Balance and Arm Muscle Strength on Creativity. Effect of Balance and Arm Muscle Strength on Creativity can be seen through the calculation results in the following table. The structural equation of substructure I is:

\section{Summary Model}

\begin{tabular}{|c|c|c|c|c|}
\hline Model & $\mathrm{R}$ & $\mathrm{R}$ Square & $\begin{array}{c}\text { Adjusted R } \\
\text { Square }\end{array}$ & $\begin{array}{c}\text { Std. Error of the } \\
\text { Estimate }\end{array}$ \\
\hline 1 & $.997^{\mathrm{a}}$ & .995 & .995 & .71577 \\
\hline
\end{tabular}

a. Predictors: (Constant), VAR00002, VAR00001

\section{ANOVAb}

\begin{tabular}{|c|c|c|c|c|c|c|}
\hline \multicolumn{2}{|r|}{ Model } & $\begin{array}{l}\text { Sum of } \\
\text { Squares }\end{array}$ & $\mathrm{df}$ & Mean Square & $\mathrm{F}$ & Sig. \\
\hline \multirow{3}{*}{1} & Regression & 6799.446 & 2 & 3399.723 & $6.636 \mathrm{E} 3$ & $.000^{\mathrm{a}}$ \\
\hline & Residual & 34.326 & 67 & .512 & & \\
\hline & Total & 6833.771 & 69 & & & \\
\hline
\end{tabular}

a. Predictors: (Constant), VAR00002, VAR00001

b. Dependent Variable: VAR00003 


\section{Coefficients $^{\mathrm{a}}$}

\begin{tabular}{|c|c|c|c|c|c|c|}
\hline & \multirow[t]{2}{*}{ Model } & \multicolumn{2}{|c|}{$\begin{array}{c}\text { Unstandardized } \\
\text { Coefficients }\end{array}$} & $\begin{array}{c}\text { Standardized } \\
\text { Coefficients }\end{array}$ & \multirow[t]{2}{*}{$\mathrm{t}$} & \multirow[t]{2}{*}{ Sig. } \\
\hline & & B & Std. Error & Beta & & \\
\hline \multirow{3}{*}{1} & (Constant) & 130.432 & 1.020 & & 127.877 & .000 \\
\hline & VAR00001 & .098 & .052 & .087 & 1.878 & .065 \\
\hline & VAR00002 & 1.041 & .053 & .912 & 19.708 & .000 \\
\hline
\end{tabular}

a. Dependent Variable: VAR00003

The structural equation of sub-structure 1 is:

$\mathrm{X} 3=0,966 \mathrm{X} 1+0,995 \mathrm{X} 2+0,005 \varepsilon 1$

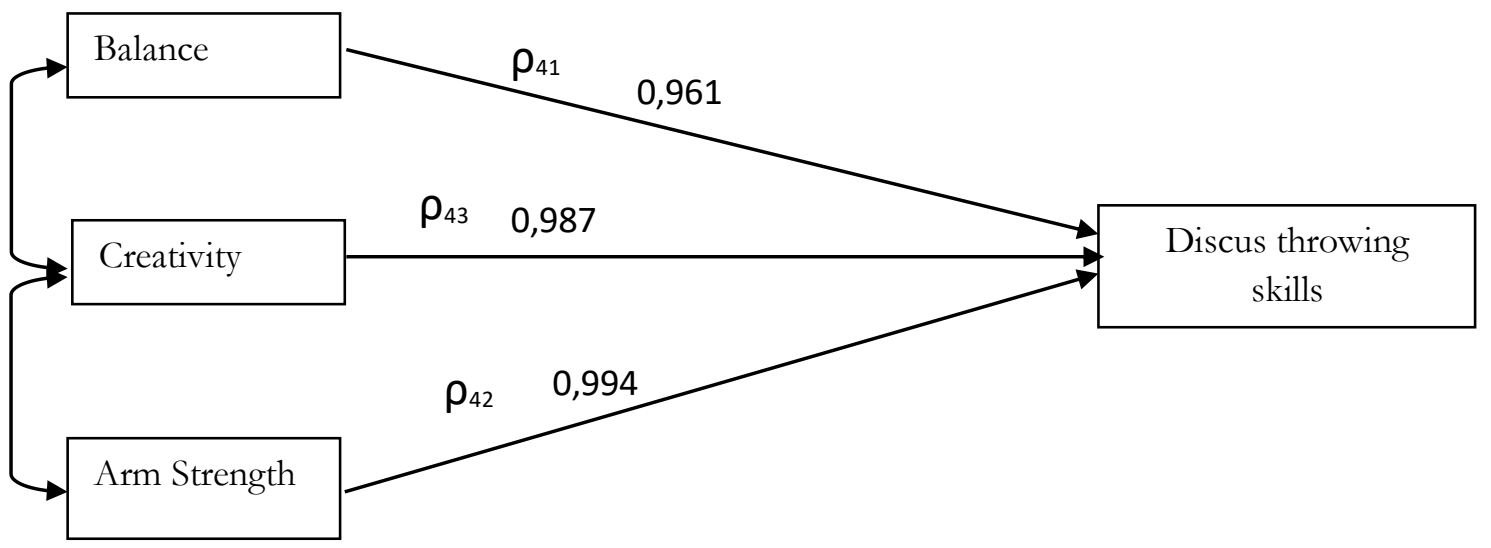

Figure 16. Substructural model of the influence of Arm Muscle Balance, Creativity on Discus Throwing Skills

The mathematical equation from Figure 16. above is $\mathrm{X}_{4}=0.961 \mathrm{X}_{1}+0.994 \mathrm{X}_{2}+0.987 \mathrm{X}_{3}+$ 0.006. Based on the sub-structure equation model 2 above, it can be explained that the Discus Throwing Skill as an endogenous variable is directly affected by Balance, Arm Muscle Strength, and Creativity as an exogenous variable and other factors beyond the three variables. The magnitude of the contribution of Balance, Arm Muscle Strength, and Creativity simultaneously affecting Discus Throwing Skills is $1-0.994=0.006$.

This figure shows the positive direct effect of Balance, Arm Muscle Strength and Creativity on Discus Throwing Skills of 0.994 , while the remaining 0.006 is influenced by other factors. In other words, the variability of Discus Throwing Skills that can be explained using Balance, Arm Muscle Strength, and Creativity variables is 0.994 , while the effect of 0.006 is caused by other variables outside the model.

In sub-structure 2 shows the combined and partial influence between Balance, Arm Muscle Strength, and Creativity. The Effect of Balance, Arm Muscle Strength, and Creativity on Discus Throwing Skills can be seen through the results of calculations in the following summary model. 


\section{ANOVA $^{\mathrm{b}}$}

\begin{tabular}{|ll|r|r|r|c|c|}
\hline \multicolumn{1}{|l|}{ Model } & \multicolumn{1}{|c|}{$\begin{array}{c}\text { Sum of } \\
\text { Squares }\end{array}$} & Df & Mean Square & F & \multicolumn{1}{c|}{ Sig. } \\
\hline 1 & Regression & 1877.237 & 3 & 625.746 & $3.572 \mathrm{E} 3$ & $.000^{2}$ \\
& Residual & 11.563 & 66 & .175 & & \\
Total & 1888.800 & 69 & & & \\
\hline
\end{tabular}

a. Predictors: (Constant), VAR00003, VAR00001, VAR00002

b. Dependent Variable: VAR00004

Coefficients $^{\mathrm{a}}$

\begin{tabular}{|c|c|c|c|c|c|c|}
\hline \multirow{2}{*}{\multicolumn{2}{|c|}{ Model }} & \multicolumn{2}{|c|}{$\begin{array}{c}\text { Unstandardized } \\
\text { Coefficients }\end{array}$} & $\begin{array}{c}\text { Standardized } \\
\text { Coefficients }\end{array}$ & \multirow[b]{2}{*}{$t$} & \multirow[b]{2}{*}{ Sig. } \\
\hline & & B & Std. Error & Beta & & \\
\hline \multirow[t]{4}{*}{1} & (Constant) & 17.627 & 9.337 & & 1.888 & .063 \\
\hline & VAR00001 & .028 & .031 & .048 & .904 & .369 \\
\hline & VAR00002 & .660 & .081 & 1.100 & 8.200 & .000 \\
\hline & VAR00003 & -.079 & .071 & -.151 & -1.110 & .271 \\
\hline
\end{tabular}

a. Dependent Variable: VAR00004

The structural equation of sub-structure 2 is:

$\mathrm{X}_{4}=0.961 \mathrm{X}_{1}+0,994 \mathrm{X}_{2}+0,987 \mathrm{X}_{3}+0,006 \varepsilon 2$

\section{Conclusion}

There is a positive direct effect of balance on Discus Throwing Skills at the Faculty of Sport Sciences Mando State University Students. This means that a good balance will result in increased discus throwing skills.

There is a positive direct effect of arm muscle strength on discus throwing skills at the students of the Faculty of Sport Science, Mando State University. This means that good arm muscle strength will result in increased discus throwing skills achieved by the student concerned.

There is a direct influence on the position of creativity fantasy on discus throwing skills at the Students of the Faculty of Sport Science, Mando State University. This means that good creativity will result in increased disc throwing skills.

There is a positive direct effect of balance on creativity in the Students of the Faculty of Sport Science, Manado State University. It means that a good balance will increase creativity.

There is a positive direct effect of arm muscle strength on creativity on the Students of the Faculty of Sport Sciences Mando State University. This means that good arm muscle strength will result in increased creativity of the students concerned. 


\section{References}

Eddy Purnomo. (2011). Dasar-dasar Gerakan Atletik Yogyakarta: Alfamedia.

Yoyo, Bahagia et al. (2000). Atletik. Jakarta: Departemen Pendidikan dan Kebudayaan.

Rud Midgley, C.S. (2000). Ensiklopedi Olahraga. Semarang: Dahara Prize Cetakan Kedua. Effhar Offset.

WJS Poerwadarminta. (1976). Kamus Bahasa Indonesia, Jakarta: Balai Pustaka.

Didi, Sugandi. (1986). Dasar-Dasar Atletik, Bandung: Penerbit Angkasa.

Clifford R. Anderson. (1975). Petunjuk Modern Kepada kesehatan, alih bahasa William Walean Bandung: Indonesia Publishing House.

Anna Sandeman, Indera. (1998). alih bahasa titin Semarang: Mandiri Jaya Abadi.

Harsono. (1986). Prinsip-prinsip Ilmu kepelatihan Jakarta: KONI Pusat.

Dadang Masnun. (1998). Biomekanika Dasar Jakarta: FPOK IKIP Jakarta.

David C. Neiman. (1990). Fitnes and Sport Medicine an Introduction California: Bull Publishing Company.

Imam Hidayat. (1986). Pengetahuan Dasar Gerak Jakarta: Kartika Jakarta Universitas Terbuka, 1986.

Russel R. Pate, Bruce Mc Clnaghan and Robert Rotella. (1993). Dasar-dasar Ilmu Kepelatihan, terjemahan Kasiyo Dwijowinoto Semarang: IKIP Press.

Don R. Kirkendal. (1988). Test Measurement New Jersey: IOWA Dubungue.

M. Sajoto. (1989). Peningkatan Kondisi Fisik dalam Olabraga Semarang: Dahara Prize.

Harsono. (1993). Latihan Kondisi Fisik Jakarta: KONI Pusat, Pusat Pendidikan dan Pelatihan.

Harsono. (1986). Ilmu Coaching Jakarta: Pusat Ilmu Olahraga KONI Pusat, Proyek Pembinaan Organisasi Olahraga dan Peningkatan Prestasi Olahraga, Januari.

Claude Bouchard. (1977-1987). Masalah-masalah Kedokteran Olahraga Latihan Olahraga dan Coaching Jakarta : Dikluspora Depdikbud.

Thomas R. Beachle and Barney R. Groves. (1997). Latihan Beban. Jakarta : PT. Raja Grafindo Persada.

Semiawan Conny. (1997). Perspektif Pendidikan Anak Berbakat Jakarta: Gramedia.

Dedi Supriadi. (1994). Kreativitas, Kebudayaan, dan Perkembangan IPTEK Bandung: Alfabeta.

Tom Wujec. (1996). Pumping Ions: Permainan dan Pelatihan yang memacu dan memicu Pikiran Anda. Alih Bahasa I.G. Triharsa M.S. Jakarta: Abdi Tadur.

Bob Samples. (2002). Revolusi Be/ajar Untuk. Anak. Penterjemah: Rahmani Astuti. Bandung: KAIFA.

Gary K. Himes. (2000). Mengembangkan Gagasan Kreatif Anda. Dalam A Dale Timpe (ed) Kreativitas. Alih Bahasa Sotyan Cikmat. Jakarta: Elex Media Komputindo

Edward de Bono. (1990). Enam Tepi Berpikir. Alih Bahasa Ridwan Max Sijabat. Jakarta: Erlangga.

Robert L. Solso. (1991). Cognitive Psychology. Boston: Selyn and Bacon, 1991.

Mihaly Csikszentmihalyi. (2005). Creativity: Flow and Psychology of Discovery and Invention New York: Harpercollins Publisher, Inc.

Michael A. West. (2000). Mengembangkan Kreativitas dalam Organisasi. Alih bahasa: Bem Hidayat Yogyakarta: Kanisius. 